\title{
Utilizing supercritical geothermal systems: a review of past ventures and ongoing research activities
}

\author{
Thomas Reinsch $^{1 *}$ (D) Patrick Dobson ${ }^{2}$, Hiroshi Asanuma ${ }^{3}$, Ernst Huenges ${ }^{1}$, Flavio Poletto ${ }^{4}$ and Bernard Sanjuan ${ }^{5}$
}

\author{
*Correspondence: Thomas. \\ Reinsch@gfz-potsdam.de \\ ${ }^{1}$ GFZ German Research \\ Centre for Geosciences, \\ Telegrafenberg, Potsdam, \\ Germany \\ Full list of author information \\ is available at the end of the \\ article
}

\begin{abstract}
Supercritical geothermal systems are very high-temperature geothermal systems that are located at depths near or below the brittle-ductile transition zone in the crust where the reservoir fluid is assumed to be in the supercritical state, that is for pure water, temperature and pressure are, respectively, in excess of $374^{\circ} \mathrm{C}$ and 221 bar. These systems have garnered attention in recent years as a possible type of unconventional geothermal resource due to their very high enthalpy fluids. Supercritical conditions are often found at the roots of volcanic-hosted hydrothermal systems. More than 25 deep wells drilled in geothermal fields such as The Geysers, Salton Sea, and on Hawaii (USA), Kakkonda (Japan), Larderello (Italy), Krafla (Iceland), Los Humeros (Mexico), and Menengai (Kenya) have encountered temperatures in excess of $374{ }^{\circ} \mathrm{C}$, and in some cases have encountered magma. Although fluid entries were documented for some of these wells, it remains an open question if permeability can be maintained at high enthalpy conditions. The IDDP-1 well at Krafla encountered magma, and ended up producing very high enthalpy fluids; however, these fluids were very corrosive and abrasive. Innovative drilling and well completion techniques are therefore needed to deal with the extreme temperatures and aggressive fluid chemistry compositions of these systems. New efforts are underway in Japan (northern Honshu), Italy (Larderello), Iceland (Reykjanes peninsula and Krafla), Mexico (Los Humeros), USA (Newberry), and New Zealand (Taupo Volcanic Zone) to investigate supercritical systems. Here, we review past studies, describe current research efforts, and outline the challenges and potential opportunities that these systems provide for international collaboration to ultimately utilize supercritical geothermal systems as a geothermal energy resource.
\end{abstract}

Keywords: Supercritical geothermal systems, Brittle-ductile transition, International collaboration

\section{Introduction}

High enthalpy geothermal systems have been harnessed for electrical power generation for over a 100 years. While the classification scheme for low, medium, and high enthalpy systems varies for different authors (Axelsson and Gunnlaugsson 2000; Benderitter and Cormy 1990; Hochstein 1990; Kaya et al. 2011; Muffler and Cataldi 1978; Nicholson 1993), reservoir temperatures above $150-225{ }^{\circ} \mathrm{C}$ are considered to be able to provide high enthalpy fluids. To date, most developed geothermal systems have temperatures of $150-300{ }^{\circ} \mathrm{C}$. Higher temperature geothermal systems $\left(T>250{ }^{\circ} \mathrm{C}\right)$ are almost always 
associated with active volcanic centers and elevated temperature gradients resulting from high heat flow caused by shallow intrusions of magma. Igneous-related geothermal systems represent a significant though unexploited energy resource; identified magmatic systems in the United States, for example, are thought to contain much more thermal energy than all known hydrothermal systems in the same region (Smith and Shaw 1975, 1979; Tester et al. 2006). In Iceland, a tenfold increase in energy output for a single well was estimated utilizing high enthalpy systems (Friðleifsson and Elders 2005). Because of the technical challenges associated with drilling deeper into the higher temperature roots of hydrothermal systems, few wells have encountered supercritical $\left(T>374{ }^{\circ} \mathrm{C}, P\right.$ $>221$ bar for pure water, $T>406{ }^{\circ} \mathrm{C}, P>298$ bar for seawater) conditions.

The transition to supercritical conditions occurs near the brittle-ductile transition zone, where magmatically dominated fluids are found in the hotter plastic rock and hydrothermal fluids circulate through the overlying cooler brittle rock (Fournier 1999). One key aspect of this environment is retrograde solubility of quartz-this might result in the sealing of any fractures generated (Fournier 1991; Saishu et al. 2014; Tsuchiya and Hirano 2007). However, on the basis of a new set of laboratory experiments on fractured granites, Watanabe et al. (2017) suggest that there is not a step-function decrease in permeability associated with the brittle-ductile transition, and that potentially exploitable resources may occur in nominally ductile granitic crust at temperatures of $375-460^{\circ} \mathrm{C}$ and depths of $2-6 \mathrm{~km}$. Recent studies have demonstrated that wells that tap supercritical fluids could have much higher productivities due to the high fluid enthalpies, which could make deeper and hotter wells economically attractive (e.g., Friðleifsson et al. 2007). Supercritical fluids also have high rates of mass transport because of their much higher ratio of buoyancy forces relative to viscous forces (Elders et al. 2014a), thus increasing efficiency. Whereas supercritical temperatures have been found in several wells in volcanic areas, supercritical pressure conditions require either drilling a very deep well or the presence of a sealing horizon allowing the pressure to exceed hydrostatic conditions. In a boiling hydrostatic hydrothermal system, pressure-temperature at each depth is governed by the boiling point-depth curve, and the critical point for pure water would be reached at a depth of about $3.6 \mathrm{~km}$ (White 1968). Exploiting the higher temperature roots of existing geothermal systems could result in increased productivity and sustainability. Recently, there have been several initiatives focused on identifying the potential opportunities and challenges associated with extreme conditions. The overall objective of these studies is to demonstrate the viability of these supercritical resources for power generation. The following sections review some of the physiochemical features associated with supercritical geothermal systems, describe previous results for wells that encountered supercritical conditions, list current research initiatives associated with these resources, and discuss potential opportunities for international collaboration. This study was initiated by a meeting on high-temperature geothermal systems at the 3rd Innovation for Cool Earth Forum (ICEF) Annual Meeting and is based on a paper presented at the 41st Workshop on Geothermal Reservoir Engineering by Dobson et al. (2017). 


\section{Initial experience with supercritical systems}

Both exploratory and production wells have encountered, in some cases unexpectedly, conditions exceeding either the critical temperature or both the critical temperature and pressure for water. Some of these wells were "dry," indicating very low permeability. All of these wells experienced serious issues with regard to rock-physical and fluid properties, leading to challenges related to drilling, completion, and fluid handling. A brief summary of some of these drilling efforts follows (also listed in Table 1).

\section{Drilling of supercritical systems in Italy}

Bertini et al. (1980) report on the drilling of well Sasso 22-4092 m depth within the Larderello geothermal field. This well was intended as an exploration well to investigate potential reservoir formations underlying the productive horizons. Nearly the entire well was drilled with complete circulation loss in very hard and inhomogeneous rock. Due to elevated temperatures and corrosive conditions, severe drilling problems such as tool deviation, drill pipe corrosion, breakage, fishing, and side tracking arose below $3000 \mathrm{~m}$. Core samples and logs could be retrieved and it was found that the formations were highly fractured to total depth. Measured temperatures reached $380{ }^{\circ} \mathrm{C}$ at $3970 \mathrm{~m}$ depth. Due to an unsuccessful primary cement job on the $95 / 8^{\prime \prime}$ production casing, and subsequent unsuccessful remedial cementations, the casing was heavily damaged to $2200 \mathrm{~m}$ depth after many string maneuvers and shocks. The well therefore had to be abandoned soon after drilling (Baron and Ungemach 1981).

A second well, San Pompeo 2, targeted the same reservoir interval as Sasso 22 (Batini et al. 1983). Again, drilling problems led to side tracking of the well. At $2930 \mathrm{~m}$ a fractured horizon was found, and the well violently blew out. This led to formation cave-in, blockage of the drill string, and accumulation of debris in the well. During subsequent cleaning operations, the well blew out again and could not be controlled, leading to abandonment. Downhole temperatures and pressures up to $394{ }^{\circ} \mathrm{C}$ and 212 bar were measured at $2560 \mathrm{~m}$ depth. Extrapolated to a depth of $2930 \mathrm{~m}$, the reservoir conditions were estimated to be $>400{ }^{\circ} \mathrm{C}$ and 240 bar (Batini et al. 1983). Close to San Pompeo 2, well Carboli 11 was drilled down to $3455 \mathrm{~m}$ in 1990. A temperature of $427^{\circ} \mathrm{C}$ was indicated at a depth of $3328 \mathrm{~m}$ using a melting alloy. In 1991, a sidetrack was drilled down to 3825 m (Ruggieri and Gianelli 1995; UNMIG 2010).

At San Vito (Mofete geothermal field), a well was drilled at 6" to $3045 \mathrm{~m}$. The well had to be side tracked two times due to loss of the bottom-hole assembly (BHA) downhole. During drilling of the first lateral, circulation was interrupted leading to gelling and coagulation of the drilling mud around the BHA. Trying to re-establish circulation by perforating the drill string failed as the explosive charge decomposed at elevated bottom-hole temperatures. In the second lateral, measurements with a zinc melting tablet indicated a bottom-hole temperature in excess of $419{ }^{\circ} \mathrm{C}$ following a 1-week shut-in period (Baron and Ungemach 1981; Fournier 1991). Nearby San Vito, high-temperature wells exhibited modest permeability (Buonasorte et al. 1995).

\section{Drilling of supercritical systems in Iceland}

A 2265-m-deep well (NJ-11) drilled at the Nesjavellir geothermal field on the NE flank of the Hengill volcano in 1988 unexpectedly encountered temperatures $>380^{\circ} \mathrm{C}$ with very 


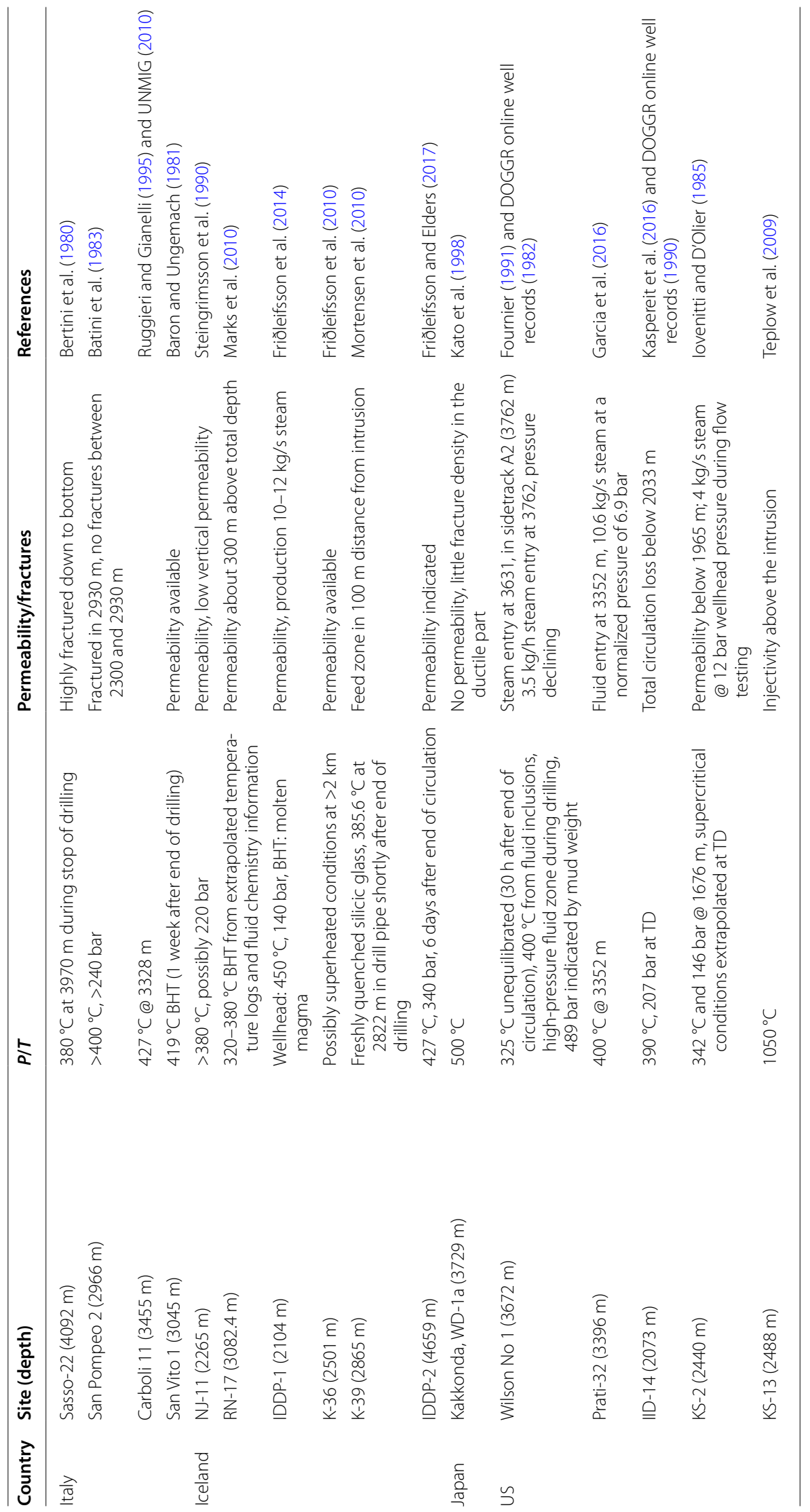




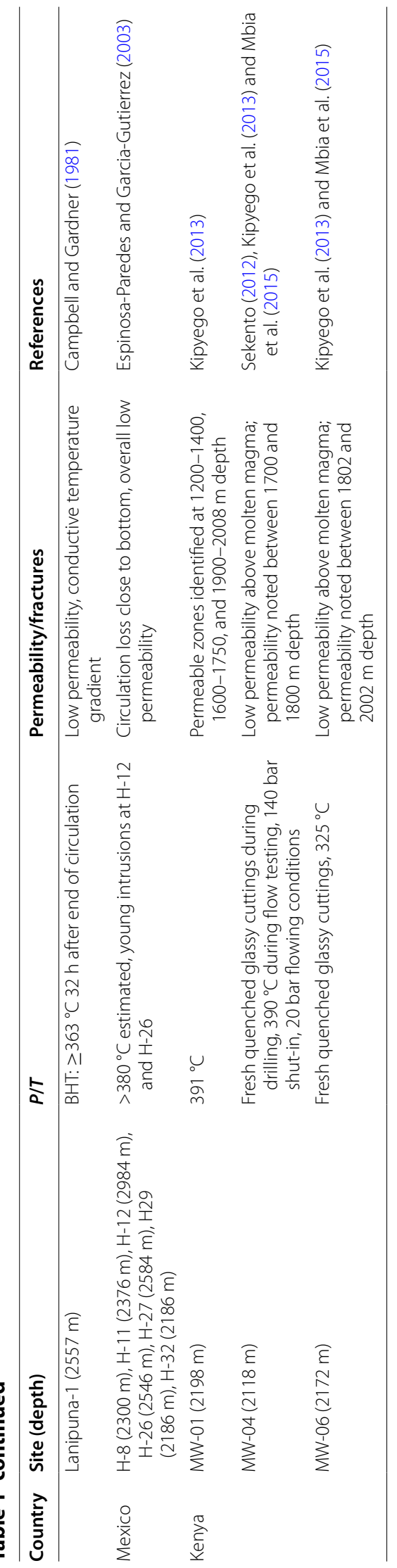


high fluid pressures and inflow rates (Fournier 1991; Steingrimsson et al. 1990). Because of the threat of a blowout at greater than hydrostatic pressures, the lower portion of the well was filled with a gravel plug. However, this well led to the concept of deliberately seeking out supercritical temperatures as part of the Deep Vision initiative in Iceland in 2000, which later transformed into the Icelandic Deep Drilling project (IDDP) (Friðleifsson and Elders 2005; Friðleifsson et al. 2007).

The primary objective of the Icelandic Deep Drilling project was to conduct deep drilling at selected sites with very high thermal gradients, to attempt to validate the concept that supercritical fluids with temperatures ranging from 450 to $600{ }^{\circ} \mathrm{C}$ could be encountered and produced from depths of 3.5 to $5 \mathrm{~km}$ and be used for commercial power generation (Elders and Friðleifsson 2010; Friðleifsson and Elders 2005; Friðleifsson et al. 2007, 2014). Observed seismic activity indicates that brittle failure occurs at these depths in this region, suggesting that there are permeable zones even at these elevated temperatures. An initial attempt was made to deepen an exploratory well on the Reykjanes peninsula (RN-17). However, the 3.1-km-deep well suffered a wellbore collapse during flow testing, and could not be deepened. The effort shifted then to the Krafla geothermal field, where the IDDP-1 well was spudded in 2008. The plan was to drill this well to a depth of $4.5 \mathrm{~km}$; however, rhyolitic magma was encountered at a depth of $2104 \mathrm{~m}$, and the well was completed just above this point at $2072 \mathrm{~m}$ (Elders and Friðleifsson 2010; Elders et al. 2014a, c). Subsequent flow testing produced superheated steam at flow rates of $10-12 \mathrm{~kg} / \mathrm{s}$ with wellhead temperatures reaching up to $450{ }^{\circ} \mathrm{C}$, fluid enthalpies of $3200 \mathrm{~kJ} / \mathrm{kg}$, and wellhead pressures of up to $140 \mathrm{bar}$ (Friðleifsson et al. 2014). The well and its associated surface equipment experienced corrosion resulting from acid gases $\left(\mathrm{HCl}, \mathrm{HF}\right.$, and $\mathrm{H}_{2} \mathrm{~S}$ ) along with silica scaling and erosion; well head valve failure ultimately led to the well being shut in (Einarsson et al. 2015). Hauksson et al. (2014) subsequently conducted field and laboratory tests that demonstrate that a variety of scrubbing techniques could be employed to mitigate the corrosive effects of the produced fluids. Continuing efforts for this project are described "Iceland Deep Drilling project" section. Close to the IDDP-1 well, K-36 was spudded in 2007 and drilled down to $2501 \mathrm{~m}$ without encountering magma. Production of highly corrosive fluid from this well indicated that the deepest aquifer at depth $>2 \mathrm{~km}$ is likely superheated or at least close to the boiling point-depth curve and very gas rich (Friðleifsson et al. 2010). Well K-39, spudded in 2008, was drilled down to 2865 m (2571 m TVD) into the Suðurhlíðar field. From 1404 to 2654 m, few cuttings were returned while drilling with almost total circulation loss. Below, no cuttings returned to surface. At $2848 \mathrm{~m}$, the drill string got stuck a few hours after drilling was completed. After unsuccessful attempts to free the drill string, it was detached with explosives in $2808 \mathrm{~m}$. The lowermost units in the BHA contained cuttings with $30 \%$ fresh, quenched glass, indicating the presence of molten rock. Temperature logging indicated three feed zones between 2000 and $2720 \mathrm{~m}$. Below, temperatures quickly increased to $385.6{ }^{\circ} \mathrm{C}$ at $2822 \mathrm{~m}$. No additional feed zone was found. The well was plugged up to $2620 \mathrm{~m}$ to avoid production of hot, potentially very acidic fluid at temperature and pressure above the rating of well completion components (Mortensen et al. 2010). In addition to the work within the IDDP project, an international consortium plans to further investigate the magma body drilled in the IDDP-1 well as part of the Krafla Magma Testbed project (KMT). The goals of KMT are detailed in "Krafla Magma Testbed project" section. 
In the vicinity of the later IDDP-2 well (see "Iceland Deep Drilling project" section) in the Reykjanes geothermal field, well RN-17 was drilled down to $3082.4 \mathrm{~m}$ in 2004/2005. Temperature measurements could only performed down to $2100 \mathrm{~m}$ due to a well obstruction. However, extrapolation of the boiling point-depth curve indicates a bottom-hole temperature of $370{ }^{\circ} \mathrm{C}$. Flow testing and fluid inclusions indicated a bottomhole temperature of $320-380^{\circ} \mathrm{C}$ [(Marks et al. 2010), and references therein].

\section{Drilling of supercritical systems in Japan}

A deep scientific exploration well was drilled in 1994-1995 at the Kakkonda geothermal field in Japan as part of the Deep Geothermal Resources Survey led by NEDO (Muraoka et al. 1998). This well, WD-1a, was drilled to a depth of $3729 \mathrm{~m}$, and penetrated through the upper hydrothermal system into a high-temperature granitic pluton with a conduction-dominated temperature gradient of up to $32{ }^{\circ} \mathrm{C} / 100 \mathrm{~m}$ and a bottom-hole temperature of $500{ }^{\circ} \mathrm{C}$ (Ikeuchi et al. 1998). An inflection in the temperature profile of the well at $\approx 380^{\circ} \mathrm{C}$ appears to indicate the brittle-ductile boundary for this system-no permeable fluid entries were observed below this transition, and a lower fracture density was observed (Kato et al. 1998). While this well did not produce supercritical fluids, it demonstrated the feasibility of drilling at these elevated temperatures using borehole cooling techniques, and confirmed that the pluton underlying the Kakkonda geothermal field was the heat source for the hydrothermal system and had even higher temperatures. This study led to research on the possible utilization of such resources for geothermal power generation (e.g., Hashida et al. 2000).

\section{Drilling of supercritical systems in the US}

Elevated temperatures have also been encountered in three geothermal systems in the United States (e.g., Elders 2015). Several high-temperature wells have been drilled at The Geysers geothermal field and its environs. The Wilson No. 1 well was drilled in 1981 outside of the main field on the flanks of Mount Hannah to a depth of $3672 \mathrm{~m}$ (Fournier 1991; DOGGR online well records 1982). While the maximum measured (unequilibrated) temperature for this well is $325^{\circ} \mathrm{C}$, fluid inclusions recovered in cuttings suggest bottom-hole temperatures of up to $400{ }^{\circ} \mathrm{C}$. A high-pressure zone was encountered near the bottom of the well, and a steam entry was observed at total depth. Casing collapse led to abandonment of the well. The highest temperatures that have been encountered to date at The Geysers were measured in a well that was deepened in 2010 as part of a US DOE-funded EGS field demonstration project in the NW Geysers high-temperature reservoir. A steam entry was encountered in the deepened Prati-32 well at $3352 \mathrm{~m}$ with a measured temperature of $400{ }^{\circ} \mathrm{C}$. Drilling difficulties caused by elevated temperatures (the well was drilled with air) led to low rates of penetration (ROP, $3 \mathrm{~m} / \mathrm{h}$ ) and extreme bit wear (the last roller cone bit only lasted $30 \mathrm{~m}$ ); thus the well was completed at a depth of $3396 \mathrm{~m}$. This well was used as the injection well for the EGS production-injection well pair for this project (Garcia et al. 2016).

A temperature of $390{ }^{\circ} \mathrm{C}$ was reported for the IID-14 well in the Salton Sea geothermal field (Kaspereit et al. 2016). This well is located on Red Hill, one of the very young rhyolite domes associated with this geothermal system. This exploration well was drilled in 1990 to a depth of 2073 m (DOGGR online well records), and was plugged 
and abandoned due to the elevated pressures encountered at depth. Although high, this temperature does not represent supercritical conditions; given that the Salton Sea fluids have extremely elevated salinities of $20-30 \%$, supercritical temperatures would need to exceed $550{ }^{\circ} \mathrm{C}$ (Driesner and Heinrich 2007). Several investigators have suggested that the Salton Sea geothermal field constitutes an ideal target for accessing supercritical geothermal fluids at reasonable $(<4 \mathrm{~km})$ depths because of the very high thermal gradient resulting from the transition from a continental rift zone to a strike-slip plate boundary (Shnell et al. 2015, 2016).

Very high temperatures were also encountered in wells KS-2 and KS-13 in the Puna geothermal field in Hawaii. KS-2 was drilled in 1982 down to a depth of $2440 \mathrm{~m}$. Severe lost circulation was encountered in the uppermost interval and cementing the casing along the loss zones was difficult. Logging until total depth was not possible because of obstructions within the well. Extrapolation of temperature and pressure conditions in well KS-2 suggests supercritical conditions at total depth. Permeable zones are assumed in the lower part of the well. Hostile well conditions led to several obstructions during flow testing (Iovenitti and D'Olier 1985). KS-13, drilled as an injector in 2005, intersected dacitic magma at a depth of $2488 \mathrm{~m}$ shortly after encountering a diorite intrusion (Teplow et al. 2009). The temperature of the melt was not measured directly downhole. Drilling problems resulted in a section of drill string being stuck and the well being completed at a depth of $2124 \mathrm{~m}$. A petrological study of dacitic glass that was recovered suggests that it had a temperature of $\approx 1050{ }^{\circ} \mathrm{C}$.

Temperatures close to supercritical conditions were reported for well Lanipuna 1 drilled down to $2557 \mathrm{~m}$ in 1981 close to the Puulena Crater on Hawaii. During drilling no lost circulation zones were encountered; however, permeable zones were interpreted from temperature profiles between 1700 and $1830 \mathrm{~m}$. A temperature log was run about $32 \mathrm{~h}$ after the end of circulation, indicating a conductive gradient from $1830 \mathrm{~m}$ to total depths. A bottom-hole temperature of $363{ }^{\circ} \mathrm{C}$ was measured, the upper temperature limit of the probe. Low permeability is consistent with the results from cutting analysis (Campbell and Gardner 1981).

\section{Drilling of supercritical systems in Mexico}

Within the Los Humeros geothermal field in Mexico, at least seven deep ( $>2100 \mathrm{~m}$ ) wells have estimated stabilized temperatures higher than $>380{ }^{\circ} \mathrm{C}$ (Elders et al. 2014b; Espinosa-Paredes and Garcia-Gutierrez 2003; García-Gutiérrez et al. 2002). Two of the wells ( $\mathrm{H}-26$ and $\mathrm{H}-12)$ appear to have encountered young intrusions at depth. Most of the wells with elevated estimated temperatures appear to lie above the boiling point-depth curve (García-Gutiérrez 2009). Most of the deep reservoir rocks at Los Humeros have relatively low permeability, making them potential targets for EGS. The supercritical portion of this field will be studied as part of the recently initiated GEMex project (see "GEMex project" section ).

\section{Drilling of supercritical systems in Kenya}

Wells MW-04 and MW-06 in the Menengai geothermal field were drilled into magma, resulting in fresh quenched glassy cuttings at 2080 and $2172 \mathrm{~m}$ depth, respectively, suggesting the presence of a shallow intrusive heat source below the caldera summit (Mbia 
et al. 2015). The drill string got stuck while drilling these intervals. During production testing of MW-04, fluid entries were observed from overlying layers and a temperature of $390^{\circ} \mathrm{C}$ was measured after 11 days of flow testing and about 1 month after the end of drilling. Pressures up to about 140 bar were observed during shut-in. At flowing conditions, bottom-hole pressure was observed to be about 20 bar (Sekento 2012).

The development of the Menengai geothermal field is currently delayed due to drilling problems. Stuck pipe problems accounted for $12 \%$ of the total drilling time in this field and were often caused by lost circulation at permeable zones and long waits for drilling water (Makuk 2013). Drilling into liquid magma pushed the drill string up, resulting in a drop of hook load. Simultaneously, circulation was blocked. Drilling at these high temperatures often leads to metal fatigue. A drill string risk management program was suggested to monitor any defects (Makuk 2013).

\section{Recent and current research efforts}

A number of serious issues have been encountered while trying to handle and utilize fluids from geothermal reservoirs at temperature and pressure conditions exceeding the supercritical conditions of water. Early experiments in high enthalpy geothermal fields clearly identified bottlenecks in terms of exploration, drilling, completing, and monitoring. The major engineering challenges remain valid today, although a lot of valuable experience was gained in recent drilling campaigns in Iceland. During some drilling campaigns, supercritical conditions were unexpected and therefore the well design was not appropriate to handle fluids at supercritical temperatures. This calls for better exploration and imaging technologies prior to drilling, as well as better reservoir models. To improve reservoir understanding at supercritical conditions, laboratory experiments at these conditions and numerical models capable of handling supercritical fluid conditions are also key.

Several drilling issues arose. As is common in geothermal wells, especially in highly fractured reservoirs, wells were drilled with total circulation loss, and sometimes a very low rate of penetration (ROP) and high bit wear. In addition, problems arose due to additives to the drilling fluid. The fluid sometimes coagulated, blocking the drill string and eventually leading to stuck pipe. Due to the high temperatures and acidic reservoir fluids, drill string fatigue and corrosion was observed, sometimes leading to breakage [(Gunnlaugsson et al. 2014; Miller 1980; Sanada et al. 1998) and references given in "Initial experience with supercritical systems" section]. Consequently fishing, and eventually side tracking, was performed. Often, cementing a casing across high permeability fractures is necessary. The high-temperature environment also affects cement setting kinetics and can lead to cement-job failures. To be able to economically access and to sustainably utilize supercritical geothermal systems, improved drilling, completion, and cementing practices have to be implemented. Completion components have to be able to handle high temperatures and pressures and acidic environments. Monitoring of subsurface conditions by measurements while drilling (MWD) can help to predict critical zones and conditions. Scaling and erosion processes have to be considered. Once a well is completed, logging and monitoring instruments have to be capable of operating at ambient downhole conditions.

Various aspects of the geothermal development chain require in-depth investigation: 
- Exploration methods for better resource assessment.

- Laboratory experiments to investigate in-situ fluid and rock properties.

- Adapted drilling and completion technologies.

- Logging and monitoring instruments and strategies.

- Numerical simulation tools capable of handling supercritical conditions.

- Field laboratories/wells to gain more knowledge about downhole conditions and test technological approaches along the entire development chain.

Complementary investigations are currently being carried out in the framework of recent or upcoming drilling campaigns in Japan, New Zealand, Mexico, and Europe. Collaborative projects in Europe are being framed with initiatives in individual member states [(Reinsch et al. 2016); http://www.geothermalresearch.eu]. Below are short summaries of recent and current activities relating to field experiments, numerical simulation methods, and high-temperature instrumentation.

\section{Field laboratories}

Recent, ongoing and proposed field studies related to supercritical geothermal systems include the Iceland Deep Drilling project (IDDP), the Krafla Magma Testbed project (KMT), the Japan Beyond Brittle project (JBBP), the DESCRAMBLE project (Drilling in dEep, Super-Critical AMBient of continental Europe) at Larderello, Italy, the Hotter and Deeper (HADES) project in the Taupo Volcanic Zone of New Zealand, the GEMex joint EU-Mexico project in Mexico, and the Newberry Deep Drilling project in the USA.

\section{Iceland Deep Drilling project}

The current phase of the Iceland Deep Drilling project (IDDP-2) involves deepening of the RN-15 well in the Reykjanes geothermal field from its original depth of $2507 \mathrm{~m}$ to a depth of $\approx 5 \mathrm{~km}$ (Fig. 1). The well was completed on January 25, 2017 at a depth of $4659 \mathrm{~m}$, where an unequilibrated bottom-hole temperature of $427^{\circ} \mathrm{C}$ was recorded together with a fluid pressure of 340 bar [(Friðleifsson and Elders 2017), see "Initial experience with supercritical systems" section]; several permeable zones were encountered below $3000 \mathrm{~m}$. Future plans for this well include petrographic analysis of retrieved core and cuttings samples to characterize the lithology and alteration of the well, running (as conditions permit) a comprehensive suite of downhole well logs, injecting cold water into the completed well to stimulate fracture permeability, and subsequent flow testing of the well to determine the nature of the formation fluids, their enthalpy, and flow characteristics, and hence their engineering and economic potential. The IDDP consortium is organized and funded by an Icelandic energy consortium (HS Orka, Landsvirkjun, Reykjavik Energy, and the National Energy Authority) with additional support from Alcoa (2007-2013) and Statoil (2007-2011). In 2015, Statoil renewed its commitment until 2020. In December 2015, the IDDP-2 became part of the European Comissionsupported project DEEPEGS (Deployment of Deep Enhanced Geothermal Systems for Sustainable Energy Business). The ultimate objective of the DEEPEGS project in Iceland is to deliver steam for electrical power generation (Friðleifsson et al. 2016). The International Continental Scientific Drilling Program (ICDP) and the US National Science Foundation (NSF) have also provided additional funding for this project. 


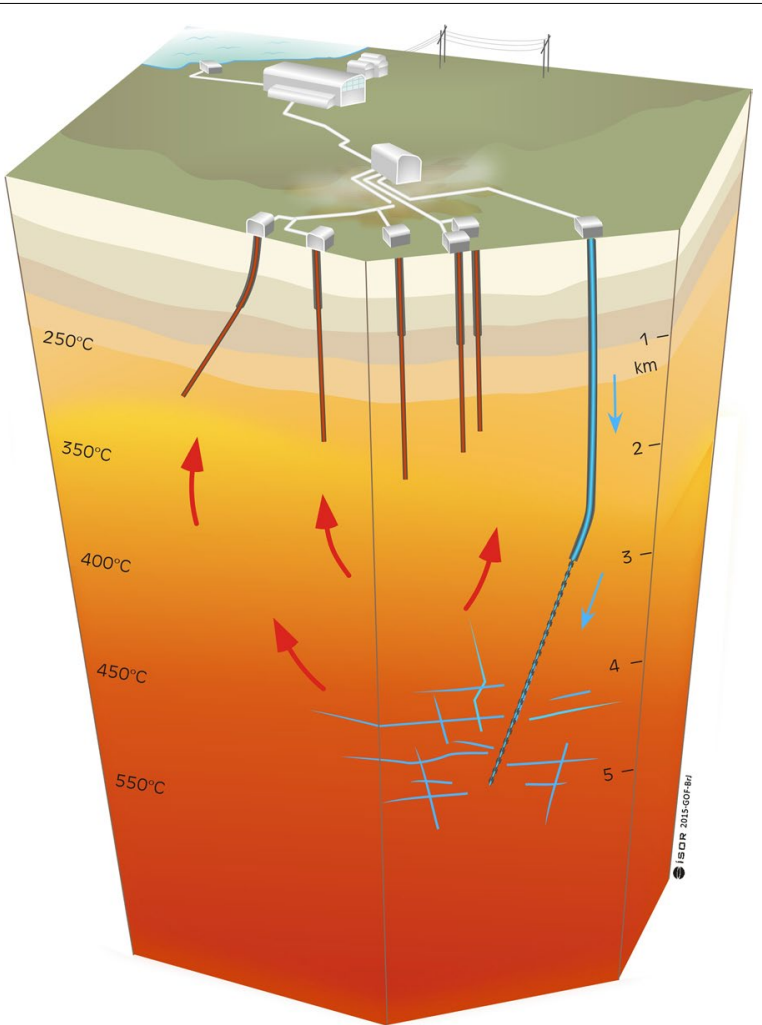

Fig. 1 Conceptual model of the Reykjanes geothermal field showing the existing conventional geothermal wells (brown) and the IDDP-2 well (blue) (Friðleifsson et al. 2016)

\section{Krafla Magma Testbed project}

Whereas the brittle-ductile transition zone was defined as the target for the IDDP project, the main goal of the Krafla Magma Testbed project is to closely observe, sample, and manipulate the transition zone from host rock to magma in order to test the concept of directly harnessing magmatic systems (e.g., Chu et al. 1990). An improved understanding of the roots of geothermal systems gained from dedicated research wells will be used to explore the potential for direct energy extraction from magma. This project plans to combine information obtained from downhole samples and subsurface measurements with surface geophysical and geochemical observations. Knowledge gained from the project will also help to establish a holistic model of volcanic systems and hence allow more reliable eruption forecasts for populated regions worldwide (Sigmundsson et al. 2016).

\section{Japan Beyond Brittle project}

The Japan Beyond Brittle project (JBBP) was initiated to investigate the feasibility of creating enhanced geothermal systems in the brittle-ductile transition zone [(Asanuma et al. 2012, 2015; Muraoka et al. 2014), Fig. 2]. This study grew out of the initial deep drilling work conducted at Kakkonda. Anticipated advantages of such a system include a potentially very large geothermal energy resource that could result in economic energy extraction, simpler reservoir design and control, reduced parasitic fluid 
losses, and reduced induced seismicity. The Tohoku area of northern Honshu in Japan has been identified as a promising target for this effort, as data from geophysical surveys in this region have identified velocity and conductivity anomalies underlying Miocene and younger calderas, suggesting the presence of shallow magma chambers that would provide a widespread source of heat (Fig. 2). Evaluation of an uplifted young graniteporphyry system in this region (Tsuchiya et al. 2016) revealed several episodes of natural hydrothermal fracturing to form different groups of veinlets (quartz veins, hydrothermal breccia veins and glassy veins) in the rock mass under supercritical and subcritical conditions. Studies of other young uplifted and exhumed plutons in Japan (e.g., Bando et al. 2003) support the idea that supercritical conditions of $400-500{ }^{\circ} \mathrm{C}$ can be found at depths of 3-5 km in association with cooling and fractured young magmatic intrusions. Current work is focused on identifying a field site where a deep well can be drilled into such a supercritical system.

\section{DESCRAMBLE project}

One of the objectives of the DESCRAMBLE project (Drilling in dEep, Super-CRitical AMBient of continentaL Europe), funded by the European Commission within the framework of the H2020 funding scheme, is to deepen the existing Venelle-2 well in the Larderello geothermal field in Italy from $2.2 \mathrm{~km}$ (and $350{ }^{\circ} \mathrm{C}$ ) to a depth of $3-3.5 \mathrm{~km}$ in 2017. As in previous attempts in the 1980s, the goal is to characterize and test the deep high-temperature resource below the currently exploited reservoir horizons (which is

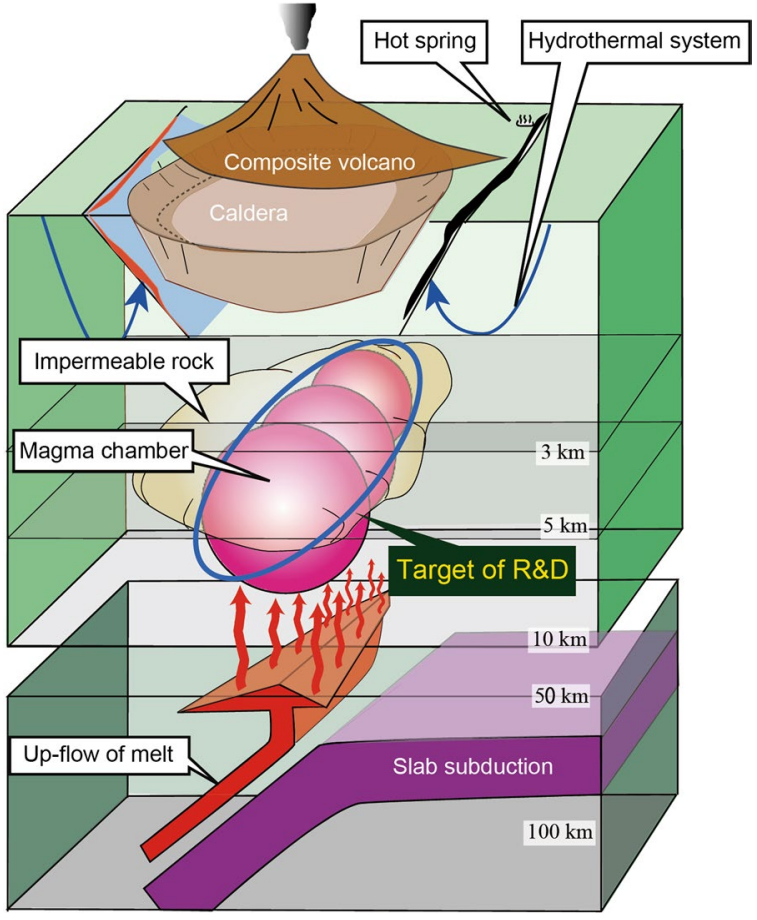

Fig. 2 Conceptual model of the JBBP project for supercritical geothermal systems in northern Honshu, Japan (Asanuma et al. 2015). These systems lie above shallow magma chambers that are associated with Miocene and younger caldera complexes in the Tohoku region 
expected to have a temperature of $\approx 450{ }^{\circ} \mathrm{C}$, e.g., Büsing et al. 2016; Liotta and Ranalli 1999; Stamnes et al. 2016). If the initial phase is successful, a pilot plant will be developed. The expectation is that productivities up to ten times those found in standard geothermal wells can be obtained from supercritical resources due to much higher enthalpy fluids. The main research objectives of DESCRAMBLE are to improve drilling and monitoring methods and to develop better ways to physically and chemically characterize deep crustal fluids and rocks (Friðleifsson et al. 2016).

\section{New Zealand Hotter and Deeper project}

Research efforts in New Zealand have included a study of the deep (5-7 km) geothermal resources in the Taupo Volcanic Zone, which are estimated to have temperatures $>400{ }^{\circ} \mathrm{C}$ and a potential of $10 \mathrm{GWe}$ (Bignall 2010; Bignall and Carey 2011). A team of investigators is conducting a comprehensive regional geophysical characterization of the Taupo Volcanic Zone to examine the links between the shallow hydrothermal systems and the deeper magmatic heat source. Newman et al. (2015) used full tensor 3D MT modeling to provide evidence of deep-seated electrically conductive plumes to $10 \mathrm{~km}$ depth. Bannister et al. (2015) conducted a passive seismic broadband survey of the region to elucidate changes in crustal velocity structure between 3 and $8 \mathrm{~km}$ depth. One of the goals of these surveys is to develop an integrated image of the brittle-ductile transition zone and identify potential deep drilling targets. Additional work has been conducted on the geochemical links between geothermal and magmatic fluids in this region (Bégué et al. 2017).

\section{GEMex project}

GEMex, a joint geothermal research project launched by Europe and Mexico within the framework of the Horizon 2020 funding scheme in 2016, aims to assess two unconventional geothermal sites in Mexico: EGS development at Acoculco and a super-hot resource in Los Humeros. This project will use innovative techniques and approaches to reservoir characterization, numerical modeling, and laboratory experiments to make the renewable energy source cost-effective and affordable for both electricity and heat production. The project's objectives include increasing knowledge of these two particular sites as well as using advanced techniques to identify deep structures to reduce drilling risks, developing stimulation methods to increase permeability, and carefully evaluating social and environmental risks associated with development of these types of resources. In a second stage, drilling into the explored reservoir is anticipated (Bruhn 2017; López Hernandez et al. 2016).

\section{Newberry Deep Drilling project}

The Newberry Deep Drilling project (NDDP) aims at drilling into the brittle-ductile transition zone at the Newberry Volcano, central Oregon state, USA. The main focus of the project is to study the heat and mass transfer in the crust in view of natural hazards and geothermal energy resource utilization. The Newberry Volcano contains one of the largest geothermal reservoirs in the western United States with a conductive thermal anomaly at $\approx 320^{\circ} \mathrm{C}$ at $3000 \mathrm{~m}$ depths (Cladouhos et al. 2016). It is assumed that at depths $<5000 \mathrm{~m}$ very high temperatures can be reached (ICDP 2017). 


\section{Conceptual models and numerical simulation studies}

There has been extensive work on conceptual models and numerical simulations of supercritical geothermal systems. Fournier (1999) developed a comprehensive conceptual model of the link between magmatic and hydrothermal systems that includes sharp thermal and fluid-pressure gradients across the brittle-ductile transition near the supercritical temperature. According to this model, episodic breaches of the higher temperature plastic zone result in discharge of fluid into the overlying brittle domain, leading to faulting, brecciation, and hydrothermal alteration and vein mineralization. Early work focused on developing simulators that could handle temperatures ranging from those found in hydrothermal systems up to those of magmatic systems (e.g., Hayba and Ingebritsen 1994). Ingebritsen et al. (2010) provide an overview of numerical modeling of magmatic hydrothermal systems, looking at the transfer of heat and metals from magma bodies into the overlying crust through fluid-rock interaction. Yano and Ishido (1998) utilized the STAR general-purpose geothermal reservoir simulator, incorporating the $\mathrm{HOTH} 2 \mathrm{O}$ equation-of-state package, to model flow to a well from a supercritical reservoir, and noted that complex behavior might be expected due to nonlinear changes in compressibility and fluid viscosity. Norton and Dutrow (2001) concurred, suggesting that magma-hydrothermal processes should be thought of as complex dynamical systems whose behavior near the supercritical region is likely chaotic; this is also consistent with the ideas of Fournier (1991), who suggested that zones of increased permeability might be episodic features associated with elevated strain rates. Watanabe et al. (2000) noted that the high heat capacity of supercritical fluids allows for more effective heat mining from high-temperature rocks.

More recent work has focused on regions with supercritical conditions, which pose challenges for many conventional reservoir model simulators due to rapid changes in the physical properties of water. Croucher and O'Sullivan (2008) updated the thermodynamic formulation used in TOUGH2 from IFC-67 to the more recent IAPWS-97 formulation to allow this code to handle supercritical conditions. O'Sullivan et al. $(2015,2016)$ have made further refinements to the AUTOUGH2 code. Magnusdottir and Finsterle (2015) developed a new equation-of-state module (EOS1sc), following the approach of Croucher and O'Sullivan (2008) to extend the applicability of iTOUGH2 to temperatures and pressures above $800{ }^{\circ} \mathrm{C}$ and $100 \mathrm{MPa}$ while obtaining better accuracy and higher computational speeds. Gunnarsson and Aradóttir (2014) have developed a simple conceptual model that invokes shallow dike intrusions as the heat source for volcanic-hosted geothermal systems. Weis and Driesner (2013) postulate the presence of a hydraulic divide between the nonstatic permeability within a supercritical reservoir and more steady fluid flow within the overlying hydrothermal system, and noted many similarities between supercritical geothermal systems and porphyry copper systems. Driesner et al. (2015) describe a modular numerical simulator platform known as the Complex Systems Modeling Platform (CSMP++), capable of simulating fluid flow and heat transfer while also capturing geo-mechanical and geochemical processes. Scott et al. (2015a, b) applied this modeling approach to evaluate processes in the supercritical zone in the IDDP-1 well. Scott et al. (2016) modeled the temporal evolution of high enthalpy geothermal systems associated with shallow intrusions, and observed that host rock permeability and composition, intrusion depth, intrusion geometry, and strain rate all play important 
roles in the thermal structure. Scott et al. (2017) noted that, for saline hydrothermal systems, the depth of the magmatic intrusions powering geothermal systems impacts the efficiency of heat transfer. In their models, for intrusions $>4 \mathrm{~km}$ deep, heat transfer is maximized by phase separation occurring via condensation, whereas less efficient heat transfer occurs via boiling in shallower $(<2.5 \mathrm{~km})$ systems.

Additional modeling work has focused on developing improved geophysical models to capture the changing physical properties associated with the brittle-ductile transition (BDT) and supercritical conditions. Carcione and Poletto (2013) proposed an elasticplastic rheology to model the BDT based on the Burgers mechanical model, including the effects of anisotropy, seismic attenuation, and temperature by the Arrhenius equation. Carcione et al. (2014) presented an algorithm to simulate full seismic wave propagation in heterogeneous media in the presence of the BDT, using the Burgers mechanical model and the Arrhenius equation to take into account viscoelastic behavior, temperature dependence, and rock melting conditions. Carcione et al. (2016) extended the theory to include poro-viscoelastic media by explicitly modeling the effects of fluids under supercritical conditions. Farina et al. (2016) applied this algorithm to simulate full waveforms, demonstrating that discontinuities associated with the transition to supercritical conditions and the presence of magmas can be seismically observable. These tools can be used for seismic characterization in conjunction with passive seismic, exploration seismic, and seismic-while-drilling methods (Poletto et al. 2011a, b).

\section{High-temperature instrumentation and method development}

A critical challenge confronting the commercial utilization of supercritical geothermal systems is the need for drilling systems, well completion methods, power plants, logging tools, and characterization methods that can withstand high temperatures and aggressive fluids. Several European Commission funded projects addressed and are currently addressing these issues. The HiTI project (High Temperature Instruments for supercritical geothermal reservoir characterization and exploitation) focused on developing hightemperature tools and methods (Ásmundsson et al. 2014; Sanjuan et al. 2010). This work focused on the development and testing of a high-temperature distributed temperature sensing (DTS) cable (Reinsch and Henninges 2010; Reinsch et al. 2013) and a wireline temperature tool, the MultiSensor memory tool that records temperature, pressure, fluid flow and casing collar locations, high-temperature borehole televiewer and resistivity logging tools, and new Na/Li geothermometers (Sanjuan et al. 2010, 2014), and high-temperature tracers (Gadalia et al. 2010; Juliusson et al. 2015). The DESCRAMBLE project developed a slick-line temperature and pressure logging tool by SINTEF that can withstand downhole conditions of $450{ }^{\circ} \mathrm{C}$ and 450 bar for up to $8 \mathrm{~h}$. The IMAGE (Integrated Methods for Advanced Geothermal Exploration) initiative led to the development of new seismic and electromagnetic investigation methods for characterizing supercritical systems (van Wees et al. 2015), and these methods have been employed at the IDDP sites in Iceland. One approach involves adaption the seismic-while-drilling method to geothermal systems (Poletto et al. 2011a,b). In addition, new laboratory setups were developed to investigate rock properties at supercritical conditions (e.g., Kummerow and Raab 2015a, b). The objective of the GeoWell project is to develop reliable, cost-effective, and environmentally safe well completion and monitoring technologies to 
accelerate the development of geothermal resources for power generation in Europe and worldwide. These technologies were deployed in traditional production wells as well as deeper wells, where the pressure may be as high as 150 bar and temperature can exceed $400{ }^{\circ} \mathrm{C}$. These technologies include all aspects of the well completion process, such as optimization of cementing and sealing procedures, selection of materials and coupling of casings, temperature and strain measurements in wells using fiber optic technologies to monitor well integrity, and development of risk-assessment methods.

\section{Conclusions}

Supercritical temperature conditions are often found at the roots of high-temperature geothermal systems. Supercritical pressure conditions are found in sufficiently deep wells or where impermeable layers were capable of trapping high-pressure conditions. Supercritical temperatures have been observed in shallower wells in cases where molten magma was hit, as in two wells in Menengai, Kenya, the IDDP-1 and K-39 wells in Iceland, and the KS-13 well in Hawaii. Pressure conditions in these wells were likely or reportedly lower than supercritical conditions. Wells encountering molten magma have been found to have a reasonable permeability in reservoir layers above the magma. For deeper high-temperature wells like the IDDP-2 and K-36 wells in Iceland, several wells at Los Humeros, Mexico, the Prati 32 well at The Geysers, IDD-14 at Salton Sea, KS-2 in Hawaii, USA, and Sasso 22 and San Vito 1 in Italy, no molten magma was found. However, zones of permeability were reported close to the bottom of some of these wells. In contrast, the deep (conductive) portion of the WD-1a well at Kakkonda or Lanipuna 1 on Hawaii did not encounter significant permeability.

For most of the wells where supercritical conditions were encountered, permeable zones were observed at depths and an inflow could be measured. For wells that encountered a magmatic intrusion, fluid emanated from the zone surrounding the magma layer, likely in a brittle state. For sites without recent intrusion, where proximity to a larger (solidifying) magma body can be assumed to be the heat source, observed permeabilities are often lower (e.g., at Kakkonda, Japan or Los Humeros, Mexico). Here, EGS-type concepts have to be considered, including stimulation technologies, thermally or hydraulically. Such concepts are currently being developed in the DEEPEGS, JBBP, and GEMex projects. Different stress regimes and rock types may impact the ability to create and sustain open fractures under supercritical conditions.

Testing and eventually producing high-temperature geothermal fluids from the current field laboratories in Iceland and Italy will help to validate new technology to handle the hostile downhole conditions.

Current developments to utilize supercritical geothermal reservoirs are mainly driven by the momentum from ongoing $\mathrm{H} 2020$ projects funded by the European Commission. To further accelerate the development of high-temperature geothermal systems worldwide, a closer collaboration between associated research institutions and the geothermal industry is key.

\section{Future steps}

Research activities along the entire geothermal value chain, as identified in "Field laboratories" section, are underway in several regions worldwide, including 
1. Exploration methods for better resource assessment
(a) Geophysical exploration methods
(b) Field stress measurements
(c) High-temperature geothermometers
(d) High-temperature tracer tests

2. EGS reservoir characterization and stimulation
(a) High-temperature logging and downhole monitoring tools, including optical methods
(b) Microseismic monitoring methods
(c) Soft stimulation methods

3. High-temperature drilling and completion methods
(a) Improved drilling methods for high-temperature systems
(b) Improved well completion methods for high-temperature systems

4. Surface systems

(a) Scrubbing and fluid-handling strategies for dealing with supercritical fluids and corrosive gases

(b) Optimized designs for surface fluid handling, power conversion, and cooling systems for supercritical fluids

5. Modeling and laboratory characterization of supercritical systems
(a) THMC modeling of supercritical systems
(b) Geologic and geophysical modeling of the brittle-ductile transition zone
(c) Calibration of models using laboratory measurements of rock and fluid proper- ties

6. Enabling international collaboration
(a) Data sharing
(b) Sharing lessons learned from field experiments
(c) Workshops
(d) Exchange opportunities for students, postdocs, and research.

To promote the successful development of supercritical geothermal systems, we identified three main areas of future international collaboration: (1) data sharing; (2) coupled process modeling; and (3) underground field laboratories. 


\section{Data sharing}

The US DOE Geothermal Technologies Office (GTO) now requires that data created by all funded projects be uploaded to the Geothermal Data Repository (GDR), a node of the National Geothermal Data System (NGDS) (Allison et al. 2013; Weers and Anderson 2015, 2016). As part of the NGDS initiative, large amounts of existing data and reports were also catalogued and uploaded into this system. The system also includes a number of data visualization and query tools, such as Geothermal Prospector (Getman et al. 2015). These data and tools are freely accessible to any interested party and can also be accessed via the geothermal energy page of the OpenEI website (http://en.openei.org/ wiki/Gateway:Geothermal), a wiki page that allows interested parties to contribute information.

One of the activities of the Integrated Methods for Advanced Geothermal Exploration (IMAGE) project has been the development of an international petrophysical property database $\left(\mathrm{P}^{3}\right)$ that can provide inputs for numerical models. This open-access repository contains peer-reviewed hydraulic, thermo-physical, and mechanical property data along with electrical resistivity and magnetic susceptibility data for rocks of geothermal interest (Bär et al. 2017).

Data sharing for supercritical systems could be expanded to include drilling experiences at elevated temperatures, as well as subsurface characterization and sampling. Sharing of lessons learned from past projects could help improve the success of future activities.

\section{Coupled process modeling}

Numerous research groups in the geothermal community have developed numerical simulators for use in coupled process modeling. As mentioned in an earlier section, there are specific challenges associated with modeling supercritical systems. One mechanism to test and validate these codes is to develop a collaborative network to assist with developing benchmarking tests and code comparison. The US DOE GTO has been conducting a geothermal code comparison study to evaluate the ability of numerical simulators to accurately model coupled thermal, hydrologic, mechanical, and chemical (THMC) processes associated with enhanced geothermal systems (e.g., Fu et al. 2016; White and Phillips 2015; White et al. 2017). These efforts are focused on developing a reliable set of modeling tools for use at the proposed US DOE Frontier Observatory for Research in Geothermal Energy (FORGE). Moreover, geophysical modeling for detection of deep structures is included in the GEMex project.

Similar efforts could be conducted on an international scale. Coupled THMC process modeling has been done for a number of benchmarking problems defined by the DEvelopment of COupled models and their VALidation against Experiments (DECOVALEX) project. This international collaboration (http://www.decovalex.org), which began in 1992, has focused on advancing the understanding and mathematical modeling of coupled thermo-hydro-mechanical (THM) and thermo-hydro-chemical (THC) processes in geological systems related to radioactive waste disposal. The participating groups have utilized many different modeling tasks, constrained by field data, to compare modeling approaches and methods-some recent examples include evaluating the effects of thermal, hydrologic, chemical, and mechanical processes on the permeability of fractured 
rocks (e.g., Bond et al. 2016; Hokr et al. 2016; McDermott et al. 2015; Rutqvist 2014). The geothermal community could emulate this type of international collaboration to advance the use of numerical simulations in supercritical systems.

Most recently, the development of robust simulators for enhanced geothermal systems focused on quantifying processes within the reservoir including fault systems (Gentier et al. 2011; Peter-Borie and Gentier 2011) and induced fractures and well paths (e.g., Vogt et al. 2012). These studies coupled existing geomodeling tools to various simulators via open-source meshing software, e.g., MeshIt (Cacace and Blöcher 2015). The goal was to extend the predictive capabilities of existing TH-coupled simulation (Jacquey and Cacace 2016; Watanabe et al. 2017) on the lifetime performance of a reservoir (Blöcher et al. 2015) by including additional mechanical and chemical feedbacks.

\section{Underground field laboratories}

Most valuable for the successful development of high-temperature geothermal systems is learning from past field activities; these expensive lessons learned provide invaluable insights that can be applied to new experiments. As a key instrument for knowledge sharing, the authors propose joint workshops on ongoing and planned high-temperature underground field laboratories listed in "Field laboratories" section. A number of underground field laboratories at low-enthalpy sites are also being utilized to improve reservoir characterization, stimulation, and monitoring techniques for enhanced geothermal systems. While these facilities do not replicate the temperature and pressure conditions associated with supercritical systems, they do permit initial testing of new technologies and approaches that could later be utilized for supercritical geothermal systems, and provide the opportunity for international collaboration.

The Grimsel Test Site in Switzerland is being used by the Swiss Competence Centre for Energy Research-Supply of Electricity (SCCER-SoE) for a suite of in-situ hydraulic stimulation, thermal circulation, and tracer experiments (Jalali et al. 2016; Jung et al. 2016; Vogler et al. 2017). The Sanford Underground Research Facility (SURF) in Lead, South Dakota, USA, has been used for hydraulic fracturing experiments in crystalline rock to characterize the stress field, understand the effects of rock fabric on fracturing, and gain experience in monitoring using a variety of geophysical methods (Oldenburg et al. 2016); it is the selected site for a new suite of EGS field experiments (the DOE Collab initiative). A geothermal research well doublet is located in Groß Schönebeck (north of Berlin, Germany). This site is equipped with a thermal fluid loop including an electrical submersible pump and a research power plant, and is being used to investigate EGS technologies for deep sedimentary basins (e.g., Blöcher et al. 2016). The Äspö Hard Rock Laboratory in Sweden has hosted a series of multi-stage hydraulic fracturing experiments in boreholes drilled in granodiorite to evaluate how differences in fluidinjection tactics (continuous, progressive, and pulse pressurization) affect the amount and intensity of induced seismicity and changes in fracture permeability (Zang et al. 2016). The US Department of Energy's Geothermal Technology Office has created the Frontier Observatory for Research in Geothermal Energy (FORGE) to develop and test the next-generation technologies needed to characterize, access, create, and sustain 
EGS reservoirs. Two sites are currently under study-the Fallon site in Nevada (Blankenship et al. 2017) and the Milford site in Utah (Allis et al. 2016), with final site selection expected in 2018.

The development of supercritical geothermal resources is a global challenge that cannot be solved by a single country alone. Cross-national research initiatives are required, where individual researchers are encouraged to implement active scientific exchange. Such initiatives have the potential to greatly increase knowledge and reduce investment costs for accessing supercritical geothermal resources. Sharing data and knowledge about coupled processes and the joint development and operation of underground field laboratories is therefore key for an efficient deployment of geothermal energy from the roots of presently exploited geothermal reservoirs.

Authors' contributions

PD wrote the draft version for the Stanford Geothermal Workshop 2017. TR revised a large part of the text. EH, BS, HA, and FP commented on the draft. Based on the contribution for the Stanford Geothermal Workshop 2017, TR prepared a first draft of this journal version that was revised by the co-authors. All authors read and approved the final manuscript.

\section{Author details}

${ }^{1}$ GFZ German Research Centre for Geosciences, Telegrafenberg, Potsdam, Germany. ${ }^{2}$ Energy Geosciences Division, Lawrence Berkeley National Laboratory, Berkeley, CA, USA. ${ }^{3}$ Fukushima Renewable Energy Institute, AIST, Koriyama, Fukushima, Japan. ${ }^{4}$ Istituto Nazionale di Oceanografia e di Geofisica Sperimentale - OGS, Trieste, Italy. ${ }^{5}$ Direction des Géoressources, Bureau de Recherches Géologiques et Minières, Orléans, France.

\section{Acknowledgements}

We thank METI, AIST, and NEDO for organizing the workshop on international joint R\&D on high-temperature geothermal development at the Innovation for Cool Earth Forum 2016 that led to this manuscript. P. Dobson was supported by the U.S. Department of Energy, Office of Energy Efficiency and Renewable Energy (EERE), Geothermal Technologies Office (GTO) under Contract No. DEAC02-05CH11231 with Lawrence Berkeley National Laboratory. Many thanks to Jeff Hulen and Dennis Kaspereit for sharing their knowledge of the IID-14 well at the Salton Sea geothermal field. Thanks also to Jeff Winick, Wilfred Elders, Jim Shnell, and Will Osborn for their constructive reviews. Many thanks to Ruggero Bertani for his contribution to the Italian presentation at ICEF with an introduction to DESCRAMBLE. For adding some high-temperature wells to the list, the authors thank Michal Kruszewski. The collaboration with Japan is supported by the European Energy Research Alliance (EERA) joint program geothermal energy (JPGE) and also by the Helmholtz Program Geothermal Energy System. F. Poletto was supported by the Istituto Nazionale di Oceanografia e di Geofisica Sperimentale - OGS, Italy. The IMAGE project (GA No. 608553) has received funding from the European Union's Seventh Programme for research, technological development and demonstration. The projects GeoWell (GA No. 654497) and GEMex (GA No. 727550) have received funding from the European Union's HORIZON 2020 research and innovation programme. The authors E. Huenges, F. Poletto, T. Reinsch, and B. Sanjuan are deeply involved in at least one of the ongoing EU-projects (GeoWell, IMAGE, and GEMex) and in the EERA JPGE. The authors are grateful to two anonymous reviewers who greatly improved the manuscript.

\section{Competing interests}

The authors declare that they have no competing interests.

Availability of data and materials

Not applicable.

Consent for publication

All authors agree to publish the material presented here.

Ethics approval and consent to participate

All authors agree to publish the material presented here.

\section{Funding}

U.S. Department of Energy, Office of Energy Efficiency and Renewable Energy (EERE), Geothermal Technologies Office (DEAC02-05CH1 1231)(GTO): PD; FP7 International Cooperation (BE) (608553): TR, BS; H2020 Societal Challenges (654497): TR, BS; H2020 Societal Challenges (727550): EH, BS, FP; Helmholtz-Gemeinschaft (Helmholtz Program Geothermal Energy Systems): EH, TR; Istituto Nazionale di Oceanografia e di Geofisica sperimentale-OGS, Italy: FP.

\section{Publisher's Note}

Springer Nature remains neutral with regard to jurisdictional claims in published maps and institutional affiliations.

Received: 2 June 2017 Accepted: 29 August 2017

Published online: 11 September 2017 


\section{References}

Allis R, Moore J, Davatzes N, Gwynn M, Hardwick C, Kirby S, McLennan J, Pankow K, Potter S, Simmons S. EGS concept testing and development at the Milford, Utah FORGE site. In: Proceedings, 41st Workshop on Geothermal Reservoir Engineering. Stanford: Stanford University; 2016. p. 13.

Allison M, Chickering C, Patten K, Anderson A, Richard S. Sustaining the national geothermal data system: considerations for a system wide approach and node maintenance. Geotherm Resour Counc Trans. 2013;37:531-8.

Asanuma H, Muraoka H, Tsuchiya N, Ito H. The concept of the Japan Beyond-Brittle project (JBBP) to develop EGS reservoirs in ductile zones. Geotherm Resour Counc Trans. 2012;36:359-64.

Asanuma H, Soma N, Tsuchiya N, Kajiwara T, Yamada S. Concept of development of supercritical geothermal resources in Japan. In: Proceedings, 2015 International Conference on Geothermal Energy in Taiwan. 2015. pp. 66-68.

Ásmundsson R, Pezard P, Sanjuan B, Henninges J, Deltombe JL, Halladay N, Lebert F, Gadalia A, Millot R, Gibert B, Violay M, Reinsch T, Naisse JM, Massiot C, Azaïs P, Mainprice D, Karytsas C, Johnston C. High temperature instruments and methods developed for supercritical geothermal reservoir characterisation and exploitation — the HiTl project. Geotherm. 2014;49(0):90-8. doi:10.1016/j.geothermics.2013.07.008.

Axelsson G, Gunnlaugsson E. Background: geothermal utilization, management and monitoring. In: Long-term monitoring of high-and low enthalpy fields under exploitation. World Geothermal Congress Short Courses, Kyushu. 2000.

Bando M, Bignall G, Sekine K, Tsuchiya N. Petrography and uplift history of the Quaternary Takidani Granodiorite: could it have hosted a supercritical (HDR) geothermal reservoir? J Volcanol Geotherm Res. 2003;120(3-4):215-34. doi:10.1016/S0377-0273(02)00399-2.

Bannister S, Bourguignon S, Sherburn S, Bertrand T. 3-D seismic velocity and attenuation in the Central Taupo Volcanic Zone, New Zealand: imaging the roots of geothermal systems. In: Proceedings, World Geothermal Congress 2015, Melbourne, Australia; 2015. p. 17.

Baron G, Ungemach P. European geothermal drilling experience-problem areas and case studies. In: International geothermal drilling and completions technology conference. Albuquerque, NM, USA. 1981. p. 24.

Batini F, Bertini G, Bottai A, Burgassi P, Cappetti G, Gianelli G, Puxeddu M. San Pompeo 2 deep well: a high temperature and high pressure geothermal system. In: Strub A, Ungemach P, editors. European geothermal update: Proceedings of the 3rd international seminar on the results of EC geothermal energy research. 1983. pp. 341-353.

Benderitter Y, Cormy G. Possible approach to geothermal research and relative costs. In: Dickson M, Fanelli M, editors. Small geothermal resources: a guide to development and utilization. New York: UNITAR; 1990. p. 59-70.

Bertini G, Giovannoni A, Stefani GC, Gianelli G, Puxeddu M, Squarci P. Deep exploration in Larderello field: Sasso 22 drilling venture. Dordrecht: Springer;1980. pp. 303-311. doi:10.1007/978-94-009-9059-3_26.

Bégué F, Deering CD, Gravley DM, Chambefort I, Kennedy BM. From source to surface: tracking magmatic boron and chlorine input into the geothermal systems of the Taupo Volcanic Zone, New Zealand. J Volcanol Geotherm Res. 2017. doi:10.1016/j.jvolgeores.2017.03.008.

Bignall G. Hotter and Deeper: New Zealand's research programme to harness its deep geothermal resources. In: Proceedings, World Geothermal Congress 2010. Bali, Indonesia. 2010. p. 3

Bignall G, Carey B. A deep (5 km?) geothermal science and drilling project for the Taupo Volcanic Zone-who wants in? In: Proceedings New Zealand Geothermal Workshop 2011. New Zealand. 2011. p. 5.

Blankenship D, Kennedy M, Majer EL, Hinz N, Faulds J, Ayling B, Blake K, Tiedeman A, Sabin A, Lazaro M, Akerley J, Kaven DSJO, Phelps G, Hickman S, Glen J, Williams C, Robertson-Tait A, Hackett L, Pettitt W. Proposed Fallon FORGE site: Phase 2 update. In: Proceedings, 42nd Workshop on Geothermal Reservoir Engineering. Stanford: Stanford University; 2017. p. 7.

Blöcher G, Cacace M, Reinsch T, Watanabe N. Evaluation of three exploitation concepts for a deep geothermal system in the North German Basin. Comput Geosci. 2015;82:120-9. doi:10.1016/j.cageo.2015.06.005.

Blöcher G, Reinsch T, Henninges J, Milsch H, Regenspurg S, Kummerow J, Francke H, Kranz S, Saadat A, Zimmermann G, Huenges E. Hydraulic history and current state of the deep geothermal reservoir Groß Schönebeck. Geothermics. 2016;63:27-43. doi:10.1016/j.geothermics.2015.07.008.

Bär K, Reinsch T, Sippel J, Strom A, Mielke P, Sass I. P3—international petrophysical property database. In: Proceedings, 42nd Workshop on Geothermal Reservoir Engineering. Stanford: Stanford University; 2017. p. 6.

Bond AE, Bruský I, Chittenden N, Feng XT, Kolditz O, Lang P, Lu R, McDermott C, Neretnieks I, Pan PZ, Šembera J, Shao $\mathrm{H}$, Yasuhara $\mathrm{H}$, Zheng $\mathrm{H}$. Development of approaches for modelling coupled thermal-hydraulic-mechanical-chemical processes in single granite fracture experiments. Environ Earth Sci. 2016;75(19):1313. doi:10.1007/ s12665-016-6117-0.

Bruhn D. GEMex: cooperation Europe-Mexico for the development of unconventional geothermal systems. In: Tagungsband, Der Geothermiekongress. 2017. p. 1.

Büsing H, Niederau J, Clauser C. Pressure-enthalpy formulation for numerical simulations of supercritical water/steam systems applied to a reservoir in Tuscany, Italy. In: Proceedings, European Geothermal Congress 2016, Strasbourg, France. 2016. p. 8.

Buonasorte G, Cameli GM, Fiordelisi A, Parotto M, Perticone I. Results of geothermal exploration in central Italy (LatiumCampania). In: World Geothermal Congress. Italy; 1995. p. 6.

Cacace M, Blöcher G. Meshlt-a software for three dimensional volumetric meshing of complex faulted reservoirs. Environ Earth Sci. 2015;74(6):5191-209. doi:10.1007/s12665-015-4537-x.

Campbell AR, Gardner MC. Geology and drilling history of Lanipua 1 geothermal test, Tokyo lands prospect, Hawaii. Tech. rep., GeothermEx, Berkeley, CA. 1981. http://hdl.handle.net/10524/22859.

Carcione JM, Poletto F. Seismic rheological model and reflection coefficients of the brittle-ductile transition. Pure Appl Geophys. 2013;170(12):2021-35. doi:10.1007/s00024-013-0643-4.

Carcione JM, Poletto F, Farina B, Craglietto A. Simulation of seismic waves at the earth's crust (brittle-ductile transition) based on the Burgers model. Solid Earth. 2014;5(2):1001-10. doi:10.5194/se-5-1001-2014.

Carcione JM, Poletto F, Farina B, Craglietto A. The Gassmann-Burgers model to simulate seismic waves at the earth crust and mantle. Pure Appl Geophys. 2016;174(3):849-63. doi:10.1007/s00024-016-1437-2. 
Chu T, Dunn J, Finger J, Rundle J, Westrich H. The magma energy program. Geotherm Resour Counc Trans. 1990;14:567-77.

Cladouhos TT, Petty S, Swyer MW, Uddenberg ME, Grasso K, Nordin Y. Results from Newberry Volcano EGS demonstration, 2010-2014. Geotherm. 2016;63:44-61. doi:10.1016/j.geothermics.2015.08.009.

Croucher AE, O'Sullivan MJ. Application of the computer code TOUGH2 to the simulation of supercritical conditions in geothermal systems. Geothermics. 2008;37(6):622-34. doi:10.1016/j.geothermics.2008.03.005.

Dobson P, Asanuma H, Huenges E, Poletto F, Reinsch T, Sanjuan B. Supercritical geothermal systems-review of past studies and ongoing research activities. In: Proceedings, 42nd Workshop on Geothermal Reservoir Engineering. Stanford: Stanford University. 2017. p. 13.

DOGGR online well records. Well Wilson 1. 1982.

DOGGR online well records. Well IID-14, Salton sea. 1990.

Driesner T, Heinrich CA. The system $\mathrm{H}_{2} \mathrm{O}-\mathrm{NaCl}$. Part I: correlation formulae for phase relations in temperature-pressure-composition space from 0 to $1000^{\circ} \mathrm{C}, 0$ to 5000 bar, and 0 to $1 \mathrm{X}_{\text {Nacl. }}$ Geochimica et Cosmochimica Acta. 2007;71(20):4880-901. doi:10.1016/j.gca.2006.01.033.

Driesner T, Weis P, Scott S. A new generation of numerical simulation tools for studying the hydrology of geothermal systems to "supercritical" and magmatic conditions. In: Proceedings, World Geothermal Congress 2015, Melbourne, Australia; 2015. p. 4.

Einarsson K, Sveinsson K, Ingason K, Kristjansson V, Holmgeirsson S. Discharge testing of magma well IDDP-1. In: Proceedings, World Geothermal Congress 2015, Melbourne, Australia; 2015. p. 13.

Elders WA. The potential for on- and off-shore high-enthalpy geothermal systems in the USA. In: Proceedings, 40th Workshop on Geothermal Reservoir Engineering. Stanford: Stanford University; 2015. p. 9.

Elders WA, Friðleifsson G. The science program of the Iceland Deep Drilling project (IDDP): a study of supercritical geothermal resources. In: Proceedings, World Geothermal Congress 2010, Bali, Indonesia; 2010. p. 9.

Elders WA, Friðleifsson G, Albertsson A. Drilling into magma and the implications of the Iceland Deep Drilling project (IDDP) for high-temperature geothermal systems worldwide. Geothermics. 2014a;49:111-8. doi:10.1016/j. geothermics.2013.05.001.

Elders WA, Izquierdo-Montalvo G, Aragon, AA, Tovar AR, Fores AM. Significance of deep zones of intense bleaching and silicification in the Los Humeros high-temperature geothermal field, Mexico: evidence of the effects of acid alteration. Geotherm Resour Counc Trans. 2014b;38:497-502.

Elders WA, Nielson D, Schiffman P, Schriener A Jr. Investigating ultra high-enthalpy geothermal systems: a collaborative initiative to promote scientific opportunities. Sci Drill. 2014c;18:35-42. doi:10.5194/sd-18-35-2014.

Espinosa-Paredes G, Garcia-Gutierrez A. Estimation of static formation temperatures in geothermal wells. Energy Conv Manag. 2003:44(8):1343-55.

Farina B, Poletto F, Carcione JM. Seismic wave propagation in poro-viscoelastic hot rocks. In: Proceedings, European Geothermal Congress 2016, Strasbourg, France; 2016. p. 7.

Fournier RO. The transition from hydrostatic to greater than hydrostatic fluid pressure in presently active continental hydrothermal systems in crystalline rock. Geophys Res Lett. 1991;18(5):955-8. doi:10.1029/91GL00966.

Fournier RO. Hydrothermal processes related to movement of fluid from plastic into brittle rock in the magmatic-epithermal environment. Econ Geol. 1999; 94(8):1193-211. doi:10.2113/gsecongeo.94.8.1193.

Friðleifsson GO, Elders WA. The Iceland Deep Drilling project: a search for deep unconventional geothermal resources. Geothermics. 2005;34:269-85. doi:10.1016/j.geothermics.2004.11.004.

Friðleifsson GO, Elders WA. The Iceland Deep Drilling project geothermal well at Reykjanes successfully reaches its supercritical target. Geotherm Resour Counc Bull. 2017;46:30-3.

Friðleifsson GO, Albertsson A, Stefansson B, Gunnlaugsson E, Adalsteinsson H. Deep Unconventional Geothermal Resources: a major opportunity to harness new sources of sustainable energy. In: Proceedings, 20th World Energy Conference, Rome. World Energy Council; 2007. p. 21

Friðleifsson GO, Pálsson B, Stefánsson B, Albertsson A, Gunnlaugsson E, Ketilsson J, Lamarche R, Andersen PE. Iceland Deep Drilling project. The first IDDP drill hole drilled and completed in 2009. In: Proceedings World Geothermal Congress; 2010. p. 4.

Friðleifsson GO, Elders WA, Albertsson A. The concept of the Iceland Deep Drilling project. Geothermics. 2014;49:2-8. doi:10.1016/j.geothermics.2013.03.004.

Friðleifsson GO, Bogason SG, Stoklosa AW, Ingolfsson HP, Vergnes P, Thorbjörnsson I, Peter-Borie M, Kohl T, Edelmann T, Bertani R, Sæther S, Palsson B. Deployment of deep enhanced geothermal systems for sustainable energy business. In: Proceedings, European Geothermal Congress 2016, Strasbourg, France; 2016. p. 8.

Fu P, McClure MW, Shiozawa S, White MD. Revisiting Fenton Hill Phase I reservoir creation and stimulation mechanisms through the GTO code comparison study. In: Proceedings, 50th US Rock Mechanics/Geomechanics Symposium, American Rock Mechanics Association, ARMA-2016-841; 2016. p. 9.

Gadalia A, Braibant G, Touzelet S, Sanjuan B. Tracing tests using organic compounds in a very high temperature geothermal field, Krafla (Iceland); 2010. Final Report, No. RP-57661-FR, BRGM.

García-Gutiérrez A. Estado térmico inicial del campo geotérmico de Los Humeros, Puebla, México. Geotermia. 2009;22:59-70.

García-Gutiérrez A, Arellano V, Barragán R, Espinosa-Paredes G. Initial temperature field in the Los Humeros geothermal reservoir. Geofísica Internacional. 2002;41(3):303-12.

Garcia J, Hartline C, Walters M, Wright M, Rutqvist J, Dobson PF, Jeanne P. The Northwest Geysers EGS demonstration project, California: Part 1: characterization and reservoir response to injection. Geotherm. 2016;63:97-119. doi:10.1016/j.geothermics.2015.08.003.

Gentier S, Rachez X, Peter-Borie M, Blaisonneau A, Sanjuan B. Transport and flow modelling of the deep geothermal exchanger between wells at Soultz-sous-Forêts (France). Geotherm Resour Counc Trans. 201 1;35:363-70.

Getman D, Anderson A, Augustine C. Supporting geothermal analysis through spatial data visualization and querying tools. Geotherm Resour Counc Trans. 2015;39:977-86. 
Gunnarsson G, Aradóttir ESP. The deep roots of geothermal systems in volcanic areas: boundary conditions and heat sources in reservoir modeling. Transp Porous Media. 2014;108(1):43-59. doi:10.1007/s11242-014-0328-1.

Gunnlaugsson E, Armannsonn H, Thorhallsson S, Steingrimsson B. Problems in geothermal operation. Scaling and corrosion. In: Short Course VI on utilization of low- and medium enthalpy geothermal resources and financial aspects of utilization, organized by UNU-GTP and LaGeo, in Santa Tecla, El Salvador. 2014.

Hashida T, Hayashi K, Niitsuma H, Matsuki K, Tsuchiya N, Nakatsuka K. Investigation of heat extraction from supercritical geothermal reservoirs. In: Proceedings, World Geothermal Congress 2000, Kyushu, Tohoku, Japan; 2000. p. 6.

Hauksson T, Markusson S, Einarsson K, Karlsdóttir SN, Einarsson Á, Möller A, Sigmarsson P. Pilot testing of handling the fluids from the IDDP-1 exploratory geothermal well, Krafla, N.E. Iceland. Geotherm. 2014;49:76-82. doi:10.1016/j. geothermics.2013.07.003.

Hayba DO, Ingebritsen SE. The computer model Hydrotherm, a three-dimensional finite-difference model to simulate ground-water flow and heat transport in the temperature range of 0 to 1,200 degrees C. US Geological Survey Water-Resources Investigations Report, 94-4045. 1994. p. 85. http://pubs.er.usgs.gov/publication/wri944045.

Hochstein M. Classification and assessment of geothermal resources. In: Dickson M, Fanelli M, editors. Small geothermal resources. Rome: UNITAR/UNDP Centre for Small Energy Resources; 1990. p. 31-59.

Hokr M, Shao H, Gardner WP, Balvín A, Kunz H, Wang Y, Vencl M. Real-case benchmark for flow and tracer transport in the fractured rock. Environ Earth Sci. 2016;75(18):1273. doi:10.1007/s12665-016-6061-z.

ICDP. Newberry Deep Drilling project (NDDP). 2017 . http://www.icdp-online.org/fileadmin/icdp/projects/doc/nddp/ Newberry_ICDP_Workshop_Call_final-1.pdf.

Ikeuchi K, Doi N, Sakagawa Y, Kamenosono H, Uchida T. High-temperature measurements in well WD-1a and the thermal structure of the Kakkonda geothermal system, Japan. Geothermics. 1998;27(5-6):591-607. doi:10.1016/ S0375-6505(98)00035-2.

Ingebritsen SE, Geiger S, Hurwitz S, Driesner T. Numerical simulation of magmatic hydrothermal systems. Rev Geophys. 2010;48:RG1002. doi:10.1029/2009RG000287.

Iovenitti L, D'Olier L. Preliminary results of drilling and testing in the Puna geothermal system, Hawaii. In: Proceedings, 10th Workshop on Geothermal Reservoir Engineering. Stanford: Stanford University; 1985. pp. 65-71.

Jacquey A, Cacace M. Modelling fully-coupled thermo-hydro-mechanical (THM) processes in fractured geothermal reservoirs using golem: a massively parallel open-source simulator. In: GeoMod 2016 conference Montpellier, France. 2016.

Jalali M, Klepikova M, Fisch H, Amann F, Loew S. Permeability enhancement in enhanced geothermal system as a result of hydraulic fracturing and jacking. In: EGU general assembly conference abstracts, vol. 18. 2016. p. 8796.

Juliusson E, Markusson S, Sigurdardottir A. Phase-specific and phase-partitioning tracer experiment in the Krafla reservoir, Iceland. In: Proceedings, World Geothermal Congress 2015, Melbourne, Australia; 2015. p. 12.

Jung M, Klepikova M, Jalali M, Fisch H, Loew S, Amann F. Geothermal reservoir characterization through active thermal testing. In: EGU general assembly conference abstracts, vol. 18. 2016. p. 12475.

Kaspereit D, Mann M, Sanyal S, Rickard B, Osborn W, Hulen J. Updated conceptual model and reserve estimate for the Salton Sea geothermal field, Imperial Valley, California. Geotherm Resour Counc Trans. 2016;40:57-66.

Kato O, Doi N, Sakagawa Y, Uchida T. Fracture systematics in and around well WD-1, Kakkonda geothermal field, Japan. Geothermics. 1998;27(5-6):609-29. doi:10.1016/50375-6505(98)00036-4.

Kaya E, Zarrouk SJ, O'Sullivan MJ. Reinjection in geothermal fields: a review of worldwide experience. Renew Sustain Energy Rev. 2011;15(1):47-68. doi:10.1016/j.rser.2010.07.032.

Kipyego E, O'Sullivan J, O'Sullivan M. An initial resource assessment of the Menengai caldera geothermal system using an air-water TOUGH2 model. In: Proceedings, 35th New Zealand Geothermal Workshop, Rotorua, New Zealand; 2013. p. 10.

Kummerow J, Raab S. Temperature dependence of electrical resistivity-Part I: experimental investigations of hydrothermal fluids. Energy Procedia. 2015a;76:240-246. doi:10.1016/j.egypro.2015.07.854.

Kummerow J, Raab S. Temperature dependence of electrical resistivity —Part Il: a new experimental set-up to study fluidsaturated rocks. Energy Procedia. 2015b;76:247-255. doi:10.1016/j.egypro.2015.07.855.

Liotta D, Ranalli G. Correlation between seismic reflectivity and rheology in extended lithosphere: southern Tuscany, inner northern Apennines, Italy. Tectonophysics. 1999;315(1-4):109-22. doi:10.1016/50040-1951 (99)00292-9.

López Hernandez A, Garduno-Monrroy V, Vargas-Medina J, Romo-Jones J, Prol-Ledesma R, Bruhn D, Flores-Armenta M. GEMex-cooperación Mxico-Europa para la investigación de sistemas geotérmicos mejorados y sistemas geotérmicos supercalientes. GEOS. 2016.

Magnusdottir L, Finsterle S. An iTOUGH2 equation-of-state module for modeling supercritical conditions in geothermal reservoirs. Geothermics. 2015;57:8-17. doi:10.1016/j.geothermics.2015.05.003.

Makuk I. Reducing geothermal drilling problems to improve performance in Menengai, Geothermal Training Programme Reports 2013, Number 16. 2013.

Marks N, Schiffman P, Zierenberg RA, Franzson H, Fridleifsson GO. Hydrothermal alteration in the Reykjanes geothermal system: insights from Iceland Deep Drilling Program well RN-17. JVolcanol Geotherm Res. 2010;189(1):172-90. doi:10.1016/j.jvolgeores.2009.10.018.

Mbia P, Mortensen A, Oskarsson N and Hardarson B. Sub-surface geology, petrology and hydrothermal alteration of the Menengai geothermal field, Kenya: case study of wells MW-02, MW-04, MW-06 and MW-07. In: Proceedings World Geothermal Congress 2015, Melbourne, Australia; 2015. p. 20.

McDermott C, Bond A, Harris AF, Chittenden N, Thatcher K. Application of hybrid numerical and analytical solutions for the simulation of coupled thermal, hydraulic, mechanical and chemical processes during fluid flow through a fractured rock. Environ Earth Sci. 2015;74(12):7837-54. doi:10.1007/s12665-015-4769-9.

Miller R. Chemistry and materials in geothermal systems. In: Casper L, Pinchback T, editors. Geothermal scaling and corrosion, STP717, ASTM international; 1980. p. 7. doi:10.1520/STP30061S.

Mortensen AK, Grönvold K, Gudmundsson Á, Steingrímsson B, Egilson T. Quenched silicic glass from well KJ-39 in Krafla, north-eastern Iceland. In: Proceedings World Geothermal Congress 2010; 2010. p. 6. 
Muffler P, Cataldi R. Methods for regional assessment of geothermal resources. Geothermics. 1978;7(2-4):53-89. doi:10.1016/0375-6505(78)90002-0.

Muraoka H, Uchida T, Sasada M, Yagi M, Akaku K, Sasaki M, Yasukawa K, Miyazaki SI, Doi N, Saito S, Sato K, Tanaka S. Deep geothermal resources survey program: igneous, metamorphic and hydrothermal processes in a well encountering $500{ }^{\circ} \mathrm{C}$ at $3729 \mathrm{~m}$ depth, Kakkonda, Japan. Geothermics. 1998;27(5-6):507-34. doi:10.1016/ S0375-6505(98)00031-5.

Muraoka H, Asanuma H, Tsuchiya N, Ito T, Mogi T, Ito H. The Japan Beyond-Brittle project. Sci Drill. 2014;17:51-9. doi:10.5194/sd-17-51-2014.

Newman G, Lindsey N, Gasperikova E, Bertrand E, Caldwell T. The importance of full impedance tensor analysis for 3D magnetotelluric imaging the roots of high temperature geothermal systems: application to the Taupo Volcanic Zone, New Zealand,. In: Proceedings, World Geothermal Congress 2015, Melbourne, Australia; 2015. p. 5.

Nicholson K. Geothermal fluids. Berlin: Springer; 1993. doi:10.1007/978-3-642-77844-5.

Norton DL, Dutrow BL. Complex behavior of magma-hydrothermal processes: role of supercritical fluid. Geochimica et Cosmochimica Acta. 2001;65(21):4009-17. doi:10.1016/S0016-7037(01)00728-1.

Oldenburg CM, Dobson PF, Wu Y, Cook PJ, Kneafsey TJ, Nakagawa S, Ulrich C, Siler DL, Guglielmi Y, Ajo-Franklin JB, et al. Intermediate-scale hydraulic fracturing in a deep mine - kISMET project summary 2016. Tech. rep., Lawrence Berkeley National Laboratory (LBNL), Berkeley, CA (United States). 2016. doi:10.2172/1338937.

O'Sullivan J, Kipyego E, Croucher A, Ofwona C, O'Sullivan M. A supercritical model of the Menengai geothermal system. In: Proceedings, World Geothermal Congress 2015, Melbourne, Australia; 2015. p. 9.

O'Sullivan J, O'Sullivan M, Croucher A. Improvements to the AUTOUGH2 supercritical simulator with extension to the air-water equation-of-state. Geotherm Resour Counc Trans. 2016;40:921-9.

Peter-Borie M, Gentier S. From the tectonic and structural analysis towards a fracture network model for hydraulically modeling the Soultz EGS (France). Geotherm Resour Counc Trans. 2011;35:507-13.

Poletto F, Corubolo P, Schleifer A, Farina B, Pollard J, Grozdanich B. Seismic while drilling for geophysical exploration in a geothermal well. Geotherm Resour Counc Trans. 2011a;35:1737-41.

Poletto F, Corubolo P, Farina B, Schleifer A, Pollard J, Peronio M, Bohm G. Drill-bit SWD and seismic interferometry for imaging around geothermal wells. In: SEG Technical Program Expanded Abstracts, San Antonio 2011 Annual Meeting. 2011 b; pp. 4319-4324.

Reinsch T, Henninges J. Temperature-dependent characterization of optical fibres for distributed temperature sensing in hot geothermal wells. Meas Sci Technol. 2010;21 (9):094022. doi:10.1088/0957-0233/21/9/094022.

Reinsch T, Henninges J, Ásmundsson R. Thermal, mechanical and chemical influences on the performance of optical fibres for distributed temperature sensing in a hot geothermal well. Environ Earth Sci. 2013;70(8):3465-3480. doi:10.1007/s12665-013-2248-8.

Reinsch T, Huenges E, Bruhn D, Thorbjörnsson I, Gavriliuc R, van Wees J. Geothermal R\&D, new projects and perspectives for basic scientific research. In: Proceedings, European Geothermal Congress 2016, Strasbourg, France; 2016. p. 4

Ruggieri G, Gianelli G. Fluid inclusion data from the Carboli 11 well, Larderello geothermal field, Italy. In: World Geothermal Congress, Italy; 1995. pp. 1087-91.

Rutqvist J. Fractured rock stress-permeability relationships from in situ data and effects of temperature and chemicalmechanical couplings. Geofluids. 2014;15(1-2):48-66. doi:10.1111/gfl.12089.

Saishu H, Okamoto A, Tsuchiya N. The significance of silica precipitation on the formation of the permeable-impermeable boundary within earth's crust. Terra Nova. 2014;26(4):253-9. doi:10.1111/ter.12093.

Sanada N, Kurata Y, Nanjo H, Ikeuchi J, Kimura S. Corrosion in acidic geothermal flows with high velocity. Proceedings 20th New Zealand geothermal workshop. New Zealand: Auckland; 1998. p. 121-6.

Sanjuan B, Millot R, Brach M, Asmundsson R, Giroud N. Use of a new sodium/lithium (Na/Li) geothermometric relationship for high-temperature dilute geothermal fluids from Iceland. In: Proceedings, World Geothermal Congress 2010, Bali, Indonesia; 2010. p. 12.

Sanjuan B, Millot R, Ásmundsson R, Brach M, Giroud N. Use of two new Na/Li geothermometric relationships for geothermal fluids in volcanic environments. Chem Geol. 2014;389:60-81. doi:10.1016/j.chemgeo.2014.09.011.

Scott S, Driesner T, Weis P. Geologic controls on supercritical geothermal resources above magmatic intrusions. Nat Commun. 2015a;6. doi:10.1038/ncomms8837.

Scott S, Driesner T, Weis P. Hydrology of a supercritical flow zone near a magmatic intrusion in the IDDP-1 well—insights from numerical modeling. In: Proceedings, World Geothermal Congress 2015, Melbourne, Australia; 2015b. p. 5.

Scott S, Driesner T, Weis P. The thermal structure and temporal evolution of high-enthalpy geothermal systems. Geothermics. 2016;62:33-47. doi:10.1016/j.geothermics.2016.02.004.

Scott S, Driesner T, Weis P. Boiling and condensation of saline geothermal fluids above magmatic intrusions. Geophys Res Lett. 2017;44(4):1696-705. doi:10.1002/2016GL071891.

Sekento LR. Geochemical and isotopic study of the Menengai geothermal field, Kenya, Geothermal Training Programme Reports 2012, Number 31. 2012.

Shnell J, Hiriart G, Nichols K, Orcutt J. Energy from ocean floor geothermal resources. In: Proceedings, World Geothermal Congress 2015, Melbourne, Australia; 2015. p. 6.

Shnell J, Newman J, Raju A, Nichols K, Elders W, Osborn W, Hiriart L G. Combining high-enthalpy geothermal generation and hydrogen production by electrolysis could both balance the transmission grid and produce non-polluting fuel for transportation. In: Proceedings, 41 st Workshop on Geothermal Reservoir Engineering. Stanford: Stanford University; 2016. p. 6.

Sigmundsson F, Eichelberger J, Papale P, Ludden J, Dingwell D, Mandeville C, Pye S, Markússon S, Árnason K, Ingólfsson H. Krafla magma testbed. In: GEORG geothermal workshop, Reykjavik, Iceland. 2016.

Smith R, Shaw H. Igneous-related geothermal systems. In: White D, Williams D, editors. Assessment of geothermal resources of the United States-1975, U.S. Geological Survey Circular, vol 726. 1975. pp. 58-83. doi:10.2172/860709.

Smith R, Shaw H. Igneous-related geothermal systems. In: Muffler L, editors. Assessment of geothermal resources of the United States, 1978, U.S. Geological Survey Circular, vol 790. 1979. pp. 12-17. doi:10.2172/6870401. 
Stamnes $\varnothing \mathrm{N}$, Røed MH, Hjelstuen M, Kolberg S, Knudsen S, Vedum J, Halladay N Development of a novel logging tool for $450^{\circ} \mathrm{C}$ geothermal wells. In: Proceedings, European Geothermal Congress 2016, Strasbourg, France; 2016. p. 6.

Steingrimsson B, Gudmundsson A, Franzson H, Gunnlaugsson E. Evidence of a supercritical fluid at depth in the Nesjavellir field. In: Proceedings, 15th Workshop on Geothermal Reservoir Engineering. Stanford: Stanford University; 1990. p. 8.

Teplow WJ, Marsh BD, Hulen J, Spielman P, Kaleikini M, Fitch DC, Rickard W. Dacite melt at the Puna geothermal venture wellfield, Big Island of Hawaii. Geotherm Resour Counc Trans. 2009;33:989-94.

Tester JW, Anderson BJ, Batchelor AS, Blackwell DD, DiPippo R, Drake EM, Garnish J, Livesay B, Moore MC, Nichols K, Petty $\mathrm{S}$, Toksöz MN, Veatch, Jr RW. The future of geothermal energy in the 21 century impact of enhanced geothermal systems (EGS) on the United States. Cambridge: MIT Press (MA). 2006. http://www1.eere.energy.gov/geothermal/ egs_technology.html.

Tsuchiya N, Hirano N. Chemical reaction diversity of geofluids revealed by hydrothermal experiments under sub- and supercritical states. Isl Arc. 2007;16(1):6-15. doi:10.1111/j.1440-1738.2007.00554.x.

Tsuchiya N, Yamada R, Uno M. Supercritical geothermal reservoir revealed by a granite-porphyry system. Geotherm. 2016;63:182-94. doi:10.1016/j.geothermics.2015.12.011.

UNMIG. Pozzi geotermici perforati in italia. 2010. http://unmig.sviluppoeconomico.gov.it.

van Wees JD, Hopman J, Dezayes C, Vernier R, Manzella A, Bruhn D, Scheck-Wenderoth M, Flovenz O, Hersir GP, Halldosdottir S, Liotta D. IMAGE: the EU funded research project integrated methods for advanced geothermal exploration. In: Proceedings World Geothermal Congress 2015, Melbourne, Australia; 2015. p. 11.

Vogler D, Settgast R, Sherman C, Gischig V, Doetsch J, Jalali R, Valley B, Evans K, Saar M, Amann F. Comparing simulations and experiments for hydraulic fracture stimulations performed at the Grimsel test site, Switzerland. In: Proceedings, 42nd Workshop on Geothermal Reservoir Engineering. Stanford: Stanford University; 2017. p. 9.

Vogt C, Kosack C, Marquart G. Stochastic inversion of the tracer experiment of the enhanced geothermal system demonstration reservoir in Soultz-sous-Forêts—revealing pathways and estimating permeability distribution. Geothermics. 2012;42:1-12. doi:10.1016/j.geothermics.2011.11.001.

Watanabe K, Niibori Y, Hashida T. Numerical study of heat extraction from supercritical geothermal reservoir. In: Proceedings, World Geothermal Congress 2000, Kyushu, Tohoku, Japan; 2000. p. 5.

Watanabe N, Numakura T, Sakaguchi K, Saishu H, Okamoto A, Ingebritsen SE, Tsuchiya N. Potentially exploitable supercritical geothermal resources in the ductile crust. Nat Geosci. 2017;10(2):140-4. doi:10.1038/NGEO2879.

Weers J, Anderson A. DOE geothermal data repository: getting more mileage out of your data. In: Proceedings, $41 \mathrm{st}$ Workshop on Geothermal Reservoir Engineering. Stanford: Stanford University; 2015. p. 6

Weers J, Anderson A. The DOE geothermal data repository and the future of geothermal data. In: Proceedings, 41st Workshop on Geothermal Reservoir Engineering, Stanford: Stanford University; 2016. p. 6.

Weis $P$, Driesner T. The interplay of non-static permeability and fluid flow as a possible pre-requisite for supercritical geothermal resources. Energy Procedia. 2013;40:102-6. doi:10.1016/j.egypro.2013.08.013.

White DE. Hydrology, activity, and heat flow of the Steamboat Springs thermal system, Washoe County, Nevada. U.S. Geological Survey Professional Paper 458-C; 1968. p. 109.

White M, Phillips B. Code comparison study fosters confidence in numerical simulation of enhanced geothermal systems. In: Proceedings, 40th Workshop on Geothermal Reservoir Engineering. Stanford, California: Stanford University; 2015. p. 12.

White MD, Fu P, McClure MW. Outcomes from a collaborative approach to a code comparison study for enhanced geothermal systems. In: Proceedings, 42nd Workshop on Geothermal Reservoir Engineering. Stanford: Stanford University; 2017. p. 12.

Yano Y, Ishido T. Numerical investigation of production behavior of deep geothermal reservoirs at super-critical conditions. Geothermics. 1998;27(5-6):705-21. doi:10.1016/50375-6505(98)00041-8.

Zang A, Stephansson O, Stenberg L, Plenkers K, Specht S, Milkereit C, Schill E, Kwiatek G, Dresen G, Zimmermann G, Dahm T, Weber M. Hydraulic fracture monitoring in hard rock at $410 \mathrm{~m}$ depth with an advanced fluid-injection protocol and extensive sensor array. Geophys J Int. 2016;208(2):790-813. doi:10.1093/gji/ggw430.

\section{Submit your manuscript to a SpringerOpen ${ }^{\circ}$ journal and benefit from:}

- Convenient online submission

- Rigorous peer review

- Open access: articles freely available online

High visibility within the field

Retaining the copyright to your article

Submit your next manuscript at $\gg$ springeropen.com 